AGRICULTURE AND BIOLOGY JOURNAL OF NORTH AMERICA

ISSN Print: 2151-7517, ISSN Online: 2151-7525, doi:10.5251/abjna.2011.2.6.929.934

(C) 2011, ScienceHuß, http://www.scihub.org/ABJNA

\title{
Economics of tillage systems and herbicides in lowland rice production at Makurdi, southern guinea savanna, Nigeria
}

\author{
Magani I.E*., Shave, P.A
}

\author{
Department of Crop and Environmental Protection, University of Agriculture, P.M.B. 2373, \\ Makurdi, Nigeria \\ ABSTRACT
}

\begin{abstract}
Two trials were conducted in 2008 and 2009 cropping season, with the principal objective of comparing the effects of tillage systems and herbicides on the yield as well as the economics of these systems in lowland rice production. The ten treatments used consist of nine (9) glyphosate at three levels $(1.44,2.16$ and $2.88 \mathrm{~kg}$ a.i/ha) that was either followed by $24-\mathrm{D}(360 \mathrm{~g} / \mathrm{l})$, propanil $(360 \mathrm{~g} / \mathrm{l})$ or propanil $(360 \mathrm{~g} / \mathrm{l})+2,4-\mathrm{D}(720 \mathrm{~g} / \mathrm{l})$ at -3 WAP and a control [conventional tillage +2 , 4$\mathrm{D}\{720 \mathrm{~g} / \mathrm{l})+$ propanil $(360 / \mathrm{l}$ at 3 weeks after planting (WAP)]. The experiments were laid out in a Randomized Complete Block Design (RCBD) with four replications using a rice variety Faro 44 (SIPI 692033). Generally throughout the period of observation (3, 6 and 9 WAP) all the zero tillage treatment recorded lower weed cover score. However, crop vigour score was highest from conventional tillage system that was followed by a mixture of 2, 4-D and propanil 3 WAP. Rice stand at 4 WAP was not significantly affected by the tillage systems as comparable results were obtained from both the zero and conventional systems. The number of grains per panicle and grain yield increased as the amount of pre-plant herbicide increased. Conventional tillage recorded the highest number of grains per panicle (145.62) and grain yield $(266.63 \mathrm{~kg} / \mathrm{ha})$ that was comparable to the zero tillage with glyphosate at the rate of $2.88 \mathrm{~kg}$ a. i/ha that was followed by a combination of 2,4-D and propanil both at the rate of $1.44 \mathrm{~kg} \mathrm{a}$.i/ha. The economics analysis (zero and conventional tillage systems) indicated that pre-plant glyphosate used at the rate of either $2.16 \mathrm{~kg}$ a.i/ha and $2.88 \mathrm{~kg}$ a.i/ha that was followed by either a mixture of 2, 4-D and propanil or used singly, gave benefit-cost ration of $4.55-4.75$. The highest benefit-cost of 4.48 was obtained in the conventional tillage.
\end{abstract}

Keywords: Economics, tillage systems, herbicides, in rice production.

\section{INTRODUCTION}

Rice has become the second most important cereal in the world after wheat in terms of production due to a recent decline in maize production (Jones, 1995). It is widely cultivated throughout the tropics; and where flood controls are effective as in South-east Asia, production is high. In sub-saharan Africa, West Africa is the leading producer and consumer of rice (WARDA, 1996). West Africa accounts for $64.2 \%$ and $61.9 \&$ of total rice production and consumption in Sub-Saharan Africa respectively. Nigeria has a leading role in rice production in West Africa. Nigeria ranks highest as both the producer and consumer of rice in the sub-region with figures slightly above $50 \%$ (WARDA, 1996). Rice is known to have been grown along the Niger for over 3000 years (Imolehin and Wada, 2006).

Rice production in Benue State accounts for as much as $40 \%$ of the total grown in Nigeria (Avav and Uza 2002). The fertile fadamas or flood plains of the
Benue River support much of that production.Most farms are small ranging in area from about 0.5 to 3 ha (BNARDA 1993). In an attempt to raise rice production levels, high yielding rice varieties have been introduced in Benue State. Hectarage per farmer could be increased if labour requirements (which are a major constraint to large hectarage) are reduced through zero tillage and chemical weed control. Akobundu (1987) recommended using a preplant broad-spectrum herbicide with quick breakdown effects before planting to clear the vegetation. The advantages of zero tillage include: - Weed control, protection of soil surface from erosion, improvement in water infiltration and retention in the soil, maintenances of soul organic matter, reduction in the soil surface temperature, maintenance of soil structure and improvement in earth worm activity (Juo and Lal, 1977). Lal (1979) enumerated soil conditions that are considered appropriate for zero tillage to include: steep slopes, shallow gravelly soils with low organic matter content and low water and 
nutrient holding capacity. Since the pioneering work on evaluation of different tillage methods in Nigeria by IITA (IITA 1971-1991), there has been a strong need for the development and evaluation of conservation tillage methods for different crops in different agro ecological zones of Nigeria. This trial was conceived to compare the effects of tillage systems and herbicides on the yield as well as the economics of the tillage systems and herbicides in lowland rice production in the Southern Guinea Savanna.

\section{MATERIALS AND METHODS}

The experiments were conducted between June and November in 2008 and 2009 at the Teaching and Research Farm of the University of Agriculture, Makurdi $\left(07^{0} 41^{, N}, 8037^{\mathrm{E}}\right)$ in the Southern Guinea Savanna. The common weed species at the experimental site include:- Rottboellia cochinchinensis (Lour), Imperata cylindrica (L.), Cyperus difformis (L.), Oryza barthis A.Chev., Chromolaena odorata (L.,), Ageratum conyzoides (L.) and Cyperus rotundus. The land was under fallow for two years prior to cultivation in 2008. Ten treatments were used as follows:- Nine glyphosate at three levels that was either followed by 2, 4-D $(360 \mathrm{~g} / \mathrm{l})$, propanil $(360 \mathrm{~g} / \mathrm{l})$ or propanil $(360 \mathrm{~g} / \mathrm{l})+2$, 4-D $(720 \mathrm{~g} / \mathrm{l})$ at $3 \mathrm{WAP}$ and a control: conventional tillage + 2 , 4-D $(720 \mathrm{~g} / \mathrm{l})+$ propanil $(360 \mathrm{~g} / \mathrm{l})$ at $3 \mathrm{WAP}$. The treatments (Table1) were replicated four times in a Randonized Complete Block Design (RCBD) with net plot sizes of $5 \mathrm{~m} \times 5 \mathrm{~m}\left(25 \mathrm{~m}^{2}\right)$. The rice variety Faro 44 (SIPI 692033) was used. The seeds were treated with metalaxyl (Apronplus ${ }^{\mathrm{R}}$ ) against pests attack. Planting was done by broadcasting the rice seeds at the rate of $80 \mathrm{~kg} / \mathrm{ha}$ to all the plots the day tillage was done. Fertilizer application was carried out by using NPK 15:15:15 at the rate of $300 \mathrm{~kg} / \mathrm{ha}$ at 3 Weeks After Planting (WAP) and thereafter top dressed with urea at the rate of $100 \mathrm{~kg} / \mathrm{ha}$ which brought total nutrients supplied to $90 \mathrm{~kg} \mathrm{~N}, 45 \mathrm{~kg} \mathrm{P} \mathrm{P}_{2} 05$ and $45 \mathrm{~kg} \mathrm{k}{ }_{2}$ 05 per hectare based on recommendations by BNARDA (1993) for the study area.

Observations made were: Weed cover score, crop stand count, crop vigour score, crop height, number of grains per panicle at harvest and the grain yield. Data were analysed with SAS (SAS 1995) following ANOVA and treatment means were compared using Duncan's New Multiple Range Test (DNMRT) at alpha $=0.05$ (Obi, 2002). Means over two years are presented here because significant differences were not detected. The prevailing labour and market costs of materials were used to obtain cost of production and revenue from grain yield of each treatment. Profit was calculated by subtracting the cost of production from revenue.

\section{RESULTS AND DISCUSSION}

Weed cover score was significantly affected by the different treatments at 3,6 and 9 WAP (Table 2). At 3WAP and 6 WAP the lowest weed cover score was obtained by pre-plant application of glyphosate at the rate of $2.88 \mathrm{~kg} \mathrm{a}$ ai/ha that was followed by $1.44 \mathrm{~kg}$ a.i/ha $2,4-D+1.44 \mathrm{~kg}$ a.i/ha propanil $\left(T_{9}\right)$. This was however not significantly different from all other treatments involving pre-plant glyphosate except in $\mathrm{T}_{1} \mathrm{~T}_{2}$ and $\mathrm{T}_{3}$ where glyphosate was applied at the rate of $1.44 \mathrm{~kg}$ a.i/ha. The lower weed cover recorded in the zero tillage treatments may be attributed to the fact the soil was not opened up for the weeds below the soil surface to germinate. A similar finding was earlier reported by Avav and Shave (2005). At 9WAP, the least weed cover score of 1.50 was obtained from the conventional tillage treatment that was followed by a combination of 2,4-D and propanil $\left(T_{10}\right)$. This was however comparable to all other treatments except preplant glyphosate at the rate of 1.44 $\mathrm{kga}$.//ha that was followed by either $2,4-\mathrm{D}$ or propanil ( $T_{1}$ and $T_{2}$ ) and pre-plant glyphosate at the rate of $2.16 \mathrm{~kg} \mathrm{a}$.i/ha that was followed only by propanil at the rate of $1.44 \mathrm{~kg}$ a.i/ha at $3 W A P$.This work was similar to earlier report that a mixture of broadleaf and grassy herbicides recorded a better weed control in rice (Adeosun and Lagoke, 2005). The highest weed cover of 2.50 obtained with $\mathrm{T}_{1}$ were comparable to $T_{2}$ and $T_{5}$ showed that pre plant glyphosate at the rate of $1.44 \mathrm{~kg}$ a.i/ha was not adequate for clean seedbed as observed at 3 and 6WAP. Avav and Shave (2005) had earlier reported that pre-plant glyphosate at the rate of $2.88-3.60 \mathrm{~kg}$ a.i/ha gave optimum weed control in lowland rice.

Table 3 present the effects of the different treatments on crop vigour score at 3,6 and 9WAP. At 3WAP, the highest crop vigour score of 3.37 was obtained from conventional tillage that was followed by a mixture of 2, 4-D and propanil 3WAP. However, T5, T6 T7 and T9 where zero tillage was carried out with various levels of glyphosate application were not significantly different from it.

Although Jasanya et al. (1997) in their evaluation of tillage methods in the southern Guinea Savanna Suggested that some level of tillage was necessary from crop performance, zero tillage has given a comparable crop performance to conventional tillage. At 6WAP all other treatments, except T6 resulted in 
significantly lower crop vigour score than the highest obtained with treatments $T_{9}$ and $T_{10}$. At 9WAP, the highest and lowest crop viigour score was obtained with $T_{10}$ and $T_{2}$, respectively.

Rice stand count at 4WAP was not significantly affected by the tillage systems as comparable results were obtained from both zero and conventional tillage systems. The lower stand count observe in treatments where glyphosate was used at lower rates could be as a result of the higher weed density at the time of rice emergence which reduced its stands through competition (Table 4). Rice plant height was similarly comparable in all treatments except in $T_{1}, T_{2}, T_{3}$ and $T_{5}$ (Table 4). This may be due to weed interference at the establishment phase of rice growth. Akobundu (1987) had earlier stressed the need for a clean seed bed before plant rice.

The number of grains per panicle and grain yield increased as the amount of pre-plant herbicide increased. Conventional tillage recorded the highest number of grains per panicle (145.62) and grain yield $(2666.63 \mathrm{~kg} / \mathrm{ha})$ which was comparable to zero tillage with glyphosate at the rate of $2.88 \mathrm{~kg}$ a.i/ha that was followed by a combination of 2, 4-D and propanil both at the rate of $1.44 \mathrm{~kg} \mathrm{a}$.i/ha (Table 4). This work confirms earlier reports by Avav and Shave (2005) who reported comparable grain yield between conventional tillage and minimum tillage in lowland rice production when both were followed by a mixture of 2, 4-D and propanil in the Southern Guinea Savanna.

Table 5 presents the economics of zero and conventional tillage systems. Pre-plant glyphosate used at the rate of either $2.16 \mathrm{~kg}$ a.i/ha and $2.88 \mathrm{~kg}$ a.i/ha that was followed by either a mixture of 2, 4-D and propanil or used singly, gave benefit cost ratio ranging from $4.55-4.75$. Conventional tillage gave a benefit - cost ratio of 4.48 .

\section{CONCLUSIONS}

1. Better weed control was achieved conventional tillage or zero tillage with pre-plant glyphosate at the rate of 2.16 $2.88 \mathrm{~kg} \mathrm{a.i/ha.}$

2. The cost of production in conventional tillage has lowered the Benefit - cost ratio (4.48) of the system.

3. Zero tillage system using glyphosate preplant at the rate of $2.16-2.88 \mathrm{~kg}$ a.i/ha gave a Benefit -cost ratio ranging from 4.55-4.75.

4. Labour requirement could be reduced in lowland rice production if zero tillage system is adopted.

Table 1: Details of Treatments used in the Trial

\begin{tabular}{|c|c|}
\hline $\mathrm{T}_{1}$ & Glyphosate at $1.44 \mathrm{~kg}$ a.i/ha $+2,4-\mathrm{D}$ at $1.44 \mathrm{~kg}$ a.i/ha 3WAP \\
\hline $\mathrm{T}_{2}$ & Glyphosate at $1.44 \mathrm{~kg}$ a.i/ha + propanil at $1.44 \mathrm{~kg}$ a.i/ha 3WAP \\
\hline $\mathrm{T}_{3}$ & Glyphosate at $1.44 \mathrm{~kg} . \mathrm{a} . \mathrm{i} / \mathrm{ha}+$ propanil at $1.44 \mathrm{~kg}$ a.i/ha $+2,4-\mathrm{D}$ at $1.44 \mathrm{~kg}$ a.i/ha 3 WAP \\
\hline $\mathrm{T}_{4}$ & Glyphosate at $2.16 \mathrm{~kg}$ a.i/ha $+2,4-\mathrm{D}$ at $1.44 \mathrm{~kg}$ a.i/ha 3WAP \\
\hline $\mathrm{T}_{5}$ & Glyphosate at $2.16 \mathrm{~kg}$ a.i/ha + propanil at $1.44 \mathrm{~kg}$ a.i/ha 3WAP \\
\hline $\mathrm{T}_{6}$ & Glyphosate at $2.16 \mathrm{~kg}$ a.i/ha + 2,4-D at $1.44 \mathrm{~kg}$ a.i/ha + propanil at $1.44 \mathrm{~kg}$ a.i/ha 3 WAP \\
\hline $\mathrm{T}_{7}$ & Glyphosate at $2.88 \mathrm{~kg}$ a.i/ha + 2,4-D at $1.44 \mathrm{~kg}$ a.i/ha 3WAP \\
\hline $\mathrm{T}_{8}$ & Glyphosate at $2.88 \mathrm{~kg}$ a.i/ha + propanil at $1.44 \mathrm{~kg}$ a.i/ha 3 WAP \\
\hline $\mathrm{T}_{9}$ & Glyphosate at $2.88 \mathrm{~kg}$ a.i/ha + 2,4-D at $1.44 \mathrm{~kg}$ a.i/ha + propanil at $1.44 \mathrm{~kg}$ a.i/ha 3 WAP \\
\hline $\mathrm{T}_{10}$ & Conventional tillage $+2,4-\mathrm{D}$ at $1.44 \mathrm{~kg}$ a.i/ha + propanil at $1.44 \mathrm{~kg}$ a.i/ha $3 \mathrm{WAP}$ \\
\hline
\end{tabular}

WAP $=$ Weeks After Planting 
Table 2: Effect of Tillage Systems and Herbicides on Weed Cover Score at Makurdi, Means for 2008 Combined.

\begin{tabular}{|c|l|l|l|}
\hline Treatments & 3WAP & 6WAP & 9WAP \\
\hline$T_{1}$ & $3.25^{\mathrm{ab}}$ & $2.37^{\mathrm{ab}}$ & $2.50^{\mathrm{a}}$ \\
\hline $\mathrm{T}_{2}$ & $3.37^{\mathrm{a}}$ & $2.62^{\mathrm{a}}$ & $2.37^{\mathrm{ab}}$ \\
\hline $\mathrm{T}_{3}$ & $2.87^{\mathrm{abc}}$ & $1.75^{\mathrm{ab}}$ & $1.62^{\mathrm{bc}}$ \\
\hline $\mathrm{T}_{4}$ & $2.37^{\mathrm{bcd}}$ & $1.87^{\mathrm{ab}}$ & $2.12^{\mathrm{abc}}$ \\
\hline $\mathrm{T}_{5}$ & $2.50^{\mathrm{abc}}$ & $2.37^{\mathrm{ab}}$ & $2.50^{\mathrm{a}}$ \\
\hline $\mathrm{T}_{6}$ & $1.87^{\mathrm{d}}$ & $1.62^{\mathrm{b}}$ & $1.87^{\mathrm{abc}}$ \\
\hline $\mathrm{T}_{7}$ & $1.87^{\mathrm{d}}$ & $1.62^{\mathrm{b}}$ & $1.62^{\mathrm{bc}}$ \\
\hline $\mathrm{T}_{8}$ & $2.00^{\mathrm{cd}}$ & $2.37^{\mathrm{ab}}$ & $2.00^{\mathrm{abc}}$ \\
\hline $\mathrm{T}_{9}$ & $1.75^{\mathrm{d}}$ & $1.62^{\mathrm{b}}$ & $2.00^{\mathrm{abc}}$ \\
\hline $\mathrm{T}_{10}$ & $3.25^{\mathrm{ab}}$ & $2.37^{\mathrm{ab}}$ & $1.50^{\mathrm{c}}$ \\
\hline$W^{\mathrm{a}}$ & & \\
\hline
\end{tabular}

WAP = Weeks After Planting

Means followed by the same letter(s) are not significantly different at $5 \%$ level of probability. Duncan's New Multiple Range Test (DNMRT).

Wee cover score scale $=1-5$, where $1=$ lowest weed density, $5=$ highest weed density.

Table 3: Effect of Tillage System and Herbicides on Crop Vigour Score at Makurdi, Means for 2008 and 2009 Combined.

\begin{tabular}{|l|l|l|l|}
\hline Treatments & 3WAP & 6WAP & 9WAP \\
\hline $\mathrm{T}_{1}$ & $1.75^{\mathrm{cd}}$ & $2.50^{\mathrm{b}}$ & $2.62^{\mathrm{de}}$ \\
\hline $\mathrm{T}_{2}$ & $1.62^{\mathrm{d}}$ & $2.62^{\mathrm{b}}$ & $2.12^{\mathrm{e}}$ \\
\hline $\mathrm{T}_{3}$ & $2.12^{\mathrm{bcd}}$ & $2.75^{\mathrm{b}}$ & $3.25^{\mathrm{cd}}$ \\
\hline $\mathrm{T}_{4}$ & $2.25^{\mathrm{bcd}}$ & $2.50^{\mathrm{b}}$ & $3.12^{\mathrm{cd}}$ \\
\hline $\mathrm{T}_{5}$ & $2.50^{\mathrm{abcd}}$ & $2.62^{\mathrm{b}}$ & $2.37^{\mathrm{e}}$ \\
\hline $\mathrm{T}_{6}$ & $2.62^{\mathrm{abc}}$ & $3.37^{\mathrm{ab}}$ & $3.87^{\mathrm{abc}}$ \\
\hline $\mathrm{T}_{7}$ & $2.62^{\mathrm{abc}}$ & $3.00^{\mathrm{b}}$ & $3.75^{\mathrm{abc}}$ \\
\hline $\mathrm{T}_{8}$ & $2.37^{\mathrm{bcd}}$ & $3.00^{\mathrm{b}}$ & $3.37^{\mathrm{bcd}}$ \\
\hline $\mathrm{T}_{9}$ & $2.87^{\mathrm{ab}}$ & $3.87^{\mathrm{a}}$ & $4.12^{\mathrm{ab}}$ \\
\hline $\mathrm{T}_{10}$ & $3.37^{\mathrm{a}}$ & $3.87^{\mathrm{a}}$ & $4.25^{\mathrm{a}}$ \\
\hline
\end{tabular}

Means followed by the letter(s) are not significantly different at 5\% level of probability Duncan's New Multiple Range Test(DNMRT).

WAP $=$ Weeks After Planting

Crop vigour score scale 1-5, where $1=$ week stand and $5=$ most healthy looking stand.

Table 4: Effects of Tillage Systems and Herbicides on Rice Stand Count, Plant Height, Grains/ Panicle and Grain Yield at Makurdi, Means for 2008 and 2009 Combined.

\begin{tabular}{|l|l|l|l|l|}
\hline Treatments & $\begin{array}{l}\text { Rice stand count } \\
\text { /m } \text { 4WAP }^{\text {2W }}\end{array}$ & $\begin{array}{l}\text { Rice plant height }(\mathbf{c m}) \\
\text { 9WAP }\end{array}$ & $\begin{array}{l}\text { Grains/Panicle } \\
\text { (No/ Panicle) }\end{array}$ & $\begin{array}{l}\text { Grain yield } \\
\text { (kg/ha) }\end{array}$ \\
\hline $\mathrm{T}_{1}$ & $1.44 .87^{\mathrm{d}}$ & $68.00^{\mathrm{c}}$ & $72.50^{\dagger}$ & $2069.63^{\dagger}$ \\
\hline $\mathrm{T}_{2}$ & $146.25^{\mathrm{d}}$ & $64.87^{\mathrm{d}}$ & $68.12^{\dagger}$ & $1962.88^{\mathrm{g}}$ \\
\hline $\mathrm{T}_{3}$ & $148.75^{\mathrm{cd}}$ & $67.75^{\mathrm{c}}$ & $85.62^{\mathrm{e}}$ & $2245.00^{\mathrm{e}}$ \\
\hline $\mathrm{T}_{4}$ & $154.62^{\mathrm{ab}}$ & $76.25^{\mathrm{ab}}$ & $122.37^{\mathrm{d}}$ & $2528.75^{\mathrm{d}}$ \\
\hline $\mathrm{T}_{5}$ & $151.62^{\mathrm{bc}}$ & $75.00^{\mathrm{b}}$ & $117.00^{\mathrm{d}}$ & $2526.25^{\mathrm{d}}$ \\
\hline $\mathrm{T}_{6}$ & $154.25^{\mathrm{ab}}$ & $76.87^{\mathrm{ab}}$ & $135.25^{\mathrm{c}}$ & $2620.50^{\mathrm{ab}}$ \\
\hline $\mathrm{T}_{7}$ & $154.12^{\mathrm{ab}}$ & $77.25^{\mathrm{ab}}$ & $137.87^{\mathrm{bc}}$ & $2606.63^{\mathrm{bc}}$ \\
\hline $\mathrm{T}_{8}$ & $153.00^{\mathrm{ab}}$ & $76.62^{\mathrm{a}}$ & $136.50^{\mathrm{bc}}$ & $2571.88^{\mathrm{cd}}$ \\
\hline $\mathrm{T}_{9}$ & $154.12^{\mathrm{ab}}$ & $77.62^{\mathrm{a}}$ & $142.12^{\mathrm{ab}}$ & $2639.88^{\mathrm{ab}}$ \\
\hline $\mathrm{T}_{10}$ & $156.62^{\mathrm{a}}$ & $78.12^{\mathrm{a}}$ & $145.62^{\mathrm{a}}$ & $2666.63^{\mathrm{a}}$ \\
\hline
\end{tabular}

Means followed by the same letter(s) are not significantly different at 5\% level of probability, Duncan's New Multiple Range Test (DNMRT).

WAP $=$ Weeks After Planting. 
Agric. Biol. J. N. Am., 2011, 2(6): 929-934

Table 5: Economic Analysis of Tillage Systems in Lowland Rice Production at Makurdi 2008-2009.

\begin{tabular}{|c|c|c|c|c|c|c|c|c|c|c|c|c|c|c|c|c|c|c|c|c|c|c|}
\hline 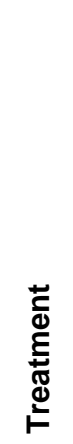 & 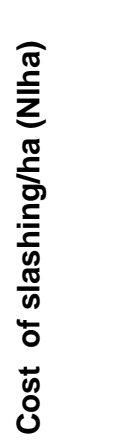 & 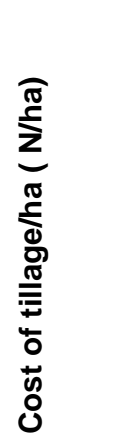 & 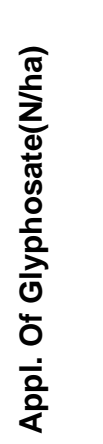 & 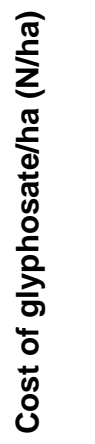 & 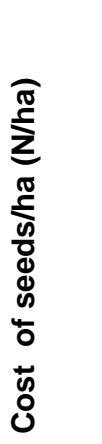 & 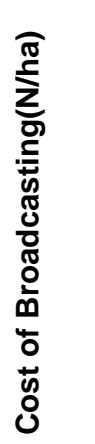 & 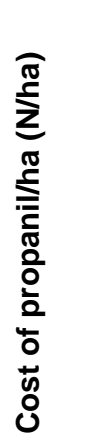 & 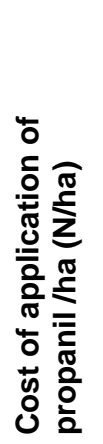 & 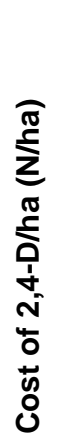 & 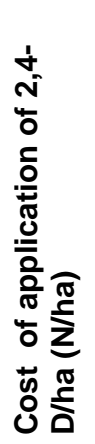 & 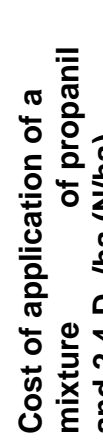 & 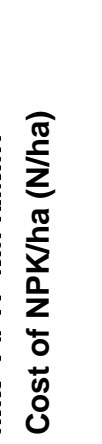 & 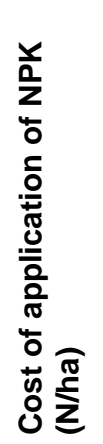 & 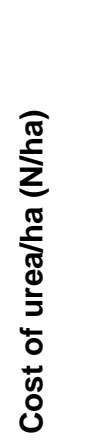 & 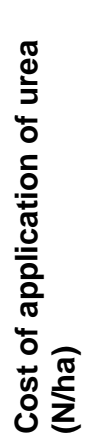 & 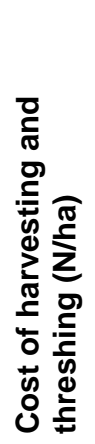 & 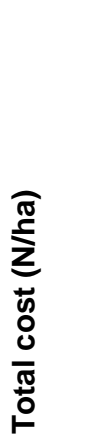 & 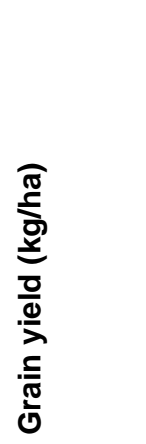 & 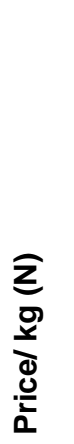 & 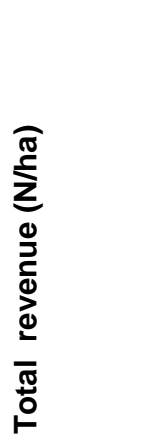 & 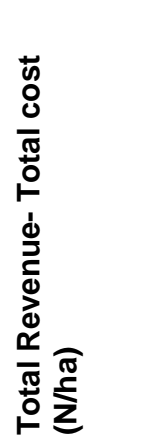 & 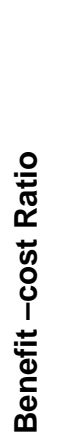 \\
\hline$\overline{\mathrm{T}_{1}}$ & - & - & 2000 & 4600 & 11200 & 1600 & & - & $\begin{array}{l}200 \\
0\end{array}$ & 4000 & - & $\begin{array}{l}1400 \\
0\end{array}$ & 3200 & 8000 & 1600 & 2000 & 72200 & 2069.63 & 140 & 289748.2 & 217548.2 & 4.01 \\
\hline$\Gamma_{2}$ & - & - & 2000 & 4600 & 11200 & 1600 & 4400 & 4000 & - & - & - & $\begin{array}{l}1400 \\
0\end{array}$ & 3200 & 8000 & 1600 & 2000 & 74600 & 1962.88 & 140 & 274803.2 & 200203.2 & 3.68 \\
\hline$T_{3}$ & - & - & 2000 & 4600 & 11200 & 1600 & 4400 & - & $\begin{array}{l}200 \\
0\end{array}$ & - & 4000 & $\begin{array}{l}1400 \\
0\end{array}$ & 3200 & 8000 & 1600 & 2000 & 76600 & 2245.00 & 140 & 314300.0 & 237700.0 & 4.10 \\
\hline$\Gamma_{4}$ & - & - & 2000 & 6900 & 11200 & 1600 & - & - & $\begin{array}{l}200 \\
0\end{array}$ & 4000 & - & $\begin{array}{l}1400 \\
0\end{array}$ & 3200 & 8000 & 1600 & 2000 & 74500 & 2528.75 & 140 & 354025.0 & 279525.0 & 4.75 \\
\hline$T_{5}$ & - & - & 2000 & 6900 & 11200 & 1600 & 4400 & 4000 & - & - & - & $\begin{array}{l}1400 \\
0\end{array}$ & 3200 & 8000 & 1600 & 2000 & 76900 & 2526.25 & 140 & 353675.0 & 276775.0 & 4.60 \\
\hline $\mathrm{T}_{6}$ & - & - & 2000 & 6900 & 11200 & 1600 & 4400 & - & $\begin{array}{l}200 \\
0\end{array}$ & - & 4000 & $\begin{array}{l}1400 \\
0\end{array}$ & 3200 & 8000 & 1600 & 2000 & 78900 & 2620.50 & 140 & 366870.0 & 287970.0 & 4.65 \\
\hline $\mathrm{T}_{7}$ & - & - & 2000 & 9200 & 11200 & 1600 & - & - & $\begin{array}{l}200 \\
0\end{array}$ & 4000 & - & $\begin{array}{l}1400 \\
0\end{array}$ & 3200 & 8000 & 1600 & 2000 & 76800 & 2606.63 & 140 & 364928.2 & 288128.2 & 4.75 \\
\hline$T_{8}$ & 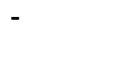 & - & 2000 & 9200 & 11200 & 1600 & 4400 & 4000 & & - & - & $\begin{array}{l}1400 \\
0\end{array}$ & 3200 & 8000 & 1600 & 2000 & 79200 & 2571.88 & 140 & 360063.2 & 280863.2 & 4.55 \\
\hline$T_{9}$ & - & - & 2000 & 9200 & 11200 & 1600 & 4400 & . & $\begin{array}{l}200 \\
0\end{array}$ & - & 4000 & $\begin{array}{l}1400 \\
0\end{array}$ & 3200 & 8000 & 1600 & 2000 & 81200 & 2639.88 & 140 & 369583.2 & 288383.2 & 4.55 \\
\hline$T_{10}$ & 12000 & 12600 & - & - & - & 1600 & 4400 & - & $\begin{array}{l}200 \\
0\end{array}$ & - & 4000 & $\begin{array}{l}1400 \\
0\end{array}$ & 3200 & 8000 & 1600 & 2000 & 83400 & 2666.63 & 140 & 373328.2 & 289928.2 & 4.48 \\
\hline
\end{tabular}

The prevailing cost of labour, planting materials and produce in both 2008 and 2009 in Makurdi were used. 


\section{REFERENCES}

Adeosun, J.O., Lagoke, S.T.O. (2005). Evaluation of herbicide treatments for weed control in upland rice (Oryza sativa L.) varieties. Nigerian Journal of Weed Science, $18: 21-36^{2}$

Akobundu, I.O. (1987).Weed Science in the tropics: Principles and Practices. Chichester: John Wiley and Sons. 522 pp.

Avav, .T., Uza, D.V.(2002). Agrivulture. In:Africa At lasses: Atlas of Nigeria, ed A.I Pigeonniere. Les Editions J.A aux Editions du jangua. Paris France Pp. 92-95

Avav, T., Shave, P.A. (2005). Weed management in lateplanted, lowland, minimum tillage rice in Benue State, Nigeria. Nigerian Journal of Weed Science, 18:57-63.

Benue State Agricultural and Rural Development Authority (BNARDA). (1993). Crop recommendations for Benue State. Extension Bulletin, No.2, 62pp.

Imolehim, E.D., Wada, A.C. (2000). Meeting the rice production and consumption demand, of Nigeria with improved technologies. International Rice commission Newsletter, Vol. 49, FAO, Rome, pp.23-41.
International Institute of Tropical Agriculture (IITA) (19711991). Annual Reports. Ibadan, Nigeria 670 pp.

Josanya, A.A., Onuwuala, A.P.,Ahaneku, I.E , (1997). Tillage effects on soul physical properties and maize production under dry land farming in Ilorin. Paper presented at the $23^{\text {rd }}$ Annual Conference of soil science society of Nigeria at Usman Danfodiyo University, Sokoto March 1-4, 1997.

Jones, M.P (1995). The rice plant and its environment. WARDA Training Guide 2. WARDA, Bouake,.pp. 2730.

Juo, A.S.R., Lal, R. (19977). The effect of fallow and continues cultivation on chemical and physical properties of an Alfisol in the tropics. Plant Soil, 47:567- 584

Lal, R. (1979). No tillage farming in the tropics. No tillage Research: Research Reports and Review University of Kentucky, Leocington, K.Y pp 103-151: In: Phillips, R.E., Thomas, G.W., Blevins, R.L (eds).

Obi, U.I. (2002). Statistical methods of detecting differences between treatment means and field experiments. AP Express publishers Limited, Nsukka, Nigeria, $117 \mathrm{pp}$. 